\title{
A STUDY OF SERUM CALCIUM LEVELS IN ESSENTIAL HYPERTENSION
}

\author{
Sachin Jaybhaye1, Neetu Agarwal2, Rajashree Khot ${ }^{3}$, Ramkumar Soni ${ }^{4}$, Vinayak Sawardekar 5 , Chandan Bansal ${ }^{6}$
}

${ }^{1}$ Assistant Professor, Department of Medicine, Grant Government Medical College, Mumbai.

${ }^{2}$ Associate Professor, Department of Medicine, Grant Government Medical College, Mumbai.

${ }^{3}$ Associate Professor, Department of Medicine, Indira Gandhi Medical College, Nagpur.

${ }^{4}$ Assistant Professor, Department of ENT, Grant Government Medical College, Mumbai.

${ }_{5}^{5}$ Associate Professor, Department of Medicine, Grant Government Medical College, Mumbai.

${ }^{6}$ Assistant Professor, Department of Medicine, Hi-Tech Hospital, Rourkela, Orissa.

\section{ABSTRACT}

\section{BACKGROUND}

Aims and Objectives- To study serum total calcium as well as ionic calcium levels in patients with essential hypertension and to correlate serum total calcium levels and ionic calcium levels with other cardiovascular risk factors like BMI and Lipid profile, etc.

\section{MATERIALS AND METHODS}

It is a descriptive study with 100 newly detected patients of essential hypertension cases and 50 age and sex matched normotensive healthy volunteers as controls. Serum calcium ionic as well as non-ionic was estimated in all the cases and controls along with other parameters. Comparisons were made using student ' $t$ ' test and chi-square for univariate analysis and multivariate analysis done finally.

\section{RESULTS}

There was no significant difference between mean level of serum total and ionic calcium in cases and controls in the present study. But study suggested young hypertensives had significantly lower levels of serum total calcium as compared to controls. Also elderly hypertensives had significantly higher levels of serum total calcium as well as ionic calcium compared to young hypertensives. Also, present study suggests that male hypertensives had significantly lower levels of serum total calcium as compared to controls, while female hypertensives had significantly higher levels of serum total calcium as well as ionic calcium compared to male hypertensives. A study showed serum total calcium has significant linear correlation with cardiovascular risk factors like high BMI, high levels of total cholesterol, Triglycerides and low HDL; however, ionic calcium does not have any significant correlation with BMI and lipid profile.

\section{CONCLUSION}

Our study concludes that though serum calcium total as well as ionic is not associated with hypertension, but regardless of this strong linear correlation of serum total calcium with BMI and hyperlipidaemia may suggest it to be a component of metabolic syndrome.

\section{KEYWORDS}

Total and Ionic Calcium Levels, Essential Hypertension, BMI, Hyperlipidaemia.

HOW TO CITE THIS ARTICLE: Jaybhaye S, Agarwal N, Khot R, et al. A study of serum calcium levels in essential hypertension. J. Evolution Med. Dent. Sci. 2017;6 (42):3278-3283, DOI: 10.14260/Jemds/2017/710

\section{BACKGROUND}

Hypertension is a universal health problem and is a major risk factor for cardiovascular, cerebrovascular and renal diseases. Essential hypertension is a multifactorial disorder that is not linked to simplistic theories of aetiology and treatment. There is no universal agreement that too little or too much dietary sodium, potassium, calcium is responsible for the genesis of essential hypertension or that changes in intake of any of these cations will constantly lower elevated blood pressure to normal levels, but this does not suggest that alteration in cation metabolism or intake may not be important in certain hypertensive subpopulations.

Financial or Other, Competing Interest: None.

Submission 12-04-2017, Peer Review 13-05-2017,

Acceptance 19-05-2017, Published 25-05-2017.

Corresponding Author:

Dr. Neetu Agarwal,

\#312 Darshana Apartments,

90 Feet Road, Near Campus Hotel,

Mulund East, Mumbai-400081.

E-mail: netagrawal@gmail.com

DOI: $10.14260 /$ jemds $/ 2017 / 710$
Epidemiological data suggest a putative role of calcium balance in blood pressure control may be important with regards to the more widely accepted, although debated hypothesis relating to sodium and potassium balance to hypertension.

The role of $\mathrm{Ca}^{++}$in the pathogenesis of essential hypertension has recently received increasing attention. In epidemiological studies, serum calcium has been found to increase with increasing levels of systolic and diastolic BP.1 Serum calcium has also been found to correlate with serum cholesterol, BMI and thus metabolic syndrome. ${ }^{2}$ Recently, serum calcium has been reported to be independent risk factor for myocardial infarction in middle aged men.1,3

Authors of early studies reported that serum calcium was significantly and positively associated with systolic and diastolic BP in both sexes ${ }^{1}$; however, other workers found lower levels of serum calcium in hypertensive patients. ${ }^{4}$

The calcium ion plays a major role as an intracellular second messenger in excitation contraction coupling in cardiac and smooth muscle cells. The free intracellular calcium concentration determines the tension in vascular smooth muscle cells, thereby resulting in peripheral vascular 
resistance. An increasing peripheral vascular resistance was a uniform finding in all types of established hypertension. Alterations in intracellular calcium are thought to be involved in the common pathway mediating secretion and action of many hormones including pressor response of catecholamines and angiotensin II. ${ }^{4}$

Some studies claim that oral supplementation of calcium causes decrease in diastolic blood pressure.5,6,7 While other studies show no significant change in blood pressure. ${ }^{8}$ Renin also plays an important role in maintaining the level of calcium. ${ }^{9}$

Due to conflicting reports on the role of serum calcium in essential hypertension, the present study is planned to estimate the serum calcium total as well as ionic in patients with essential hypertension and compare it with normal individuals and also to correlate it with other cardiovascular risk factors like BMI and lipid profile.

\section{Aims and Objectives of the Present Study}

1) To study serum total calcium as well as ionic calcium levels in patients with essential hypertension.

2) To correlate serum total calcium levels and ionic calcium levels with other cardiovascular risk factors like BMI and Lipid profile, etc.

\section{MATERIALS AND METHODS}

It is a descriptive study with 100 newly detected patients of essential hypertension cases and 50 age and sex matched normotensive healthy volunteers as controls. Only 50 controls were chosen as against 100 cases due to limited resources in government sector and non-availability of ionic calcium at our hospital. Hence, due to financial constraints 50 controls were chosen. Statistician was consulted for the same. Selection of case was based on patients of essential hypertension, newly detected not previously on antihypertensive therapy attending Medicine OPD, Cardiology OPD or admitted in medicine wards. Diagnosis of hypertension was made according to $7^{\text {th }}$ report of Joint National Committee, a WHO Expert Committee on prevention, detection, evaluation and treatment of high blood pressure. ${ }^{10}$ This classification was based on average of two or more properly measured supine BP readings on each of two or more visits.

\section{According to JNC VII Criteria ${ }^{10}$ Hypertension was defined} as a record of-

1. Systolic blood pressure $\geq 140 \mathrm{mmHg}$ and/or

2. Diastolic $\mathrm{BP} \geq 90 \mathrm{mmHg}$.

\section{Following Patients were excluded from Study}

- Secondary hypertension.

- Diabetes mellitus.

- Patients already on antihypertensive therapy.

- Patients on calcium or multi-mineral supplementation therapy.

- Patients of renal disease, i.e. chronic renal failure, diabetic nephropathy or hypertensive nephropathy.

Age and Sex Matched 50 Healthy Controls were taken who were-

1. Attending OPD for physical checkup.

2. Unrelated attendants who visited the case.

3. Paramedical staffs and their family.
Statistical Analysis

1. For statistical analysis, Statistical Software SPSS Programme on a personal computer is used.

2. Demographic Data- Demographic characters like age and sex are mentioned.

Age is expressed in mean and standard deviation (SD).

3. Descriptive Statistics of all Characters- Descriptive statistics of demographic characters like (age, sex) and other parameters like BMI, serum total calcium and ionic calcium, lipid profile are mentioned. Data are expressed as mean and standard deviation. Independent sample ' $\mathrm{t}$ ' test and chi-square test is used to analyse all baseline characteristics. Linear regression is used to find out correlation between variables.

4. For all statistical comparison, $\mathrm{p}$ value $\leq 0.05$ is considered statistically significant.

\section{RESULTS}

In the present study, 100 cases and 50 age and sex matched healthy controls were studied. There was more number of young hypertensives (59\%), i.e. $<59$ years of age in present study. Maximum number of patients (30\% of cases and $30 \%$ of controls) were in the age group of 50 to 59 yrs. Comparison of gender shows that there were equal percentage of male and female in both the groups $(56 \%$ of male and $44 \%$ of female in both the groups).

Smoking was the most common risk factor observed and was seen in $48 \%$ of the cases; $33 \%$ of the cases had hypertension in first-degree relatives. As regards to other risk factors, sedentary lifestyle and obesity were observed in $23 \%$ and $20 \%$ of the cases respectively (Table 1 ).

\begin{tabular}{|c|c|c|c|}
\hline $\begin{array}{c}\text { Sl. } \\
\text { No. }\end{array}$ & Risk Factors & $\begin{array}{c}\text { Cases } \\
(\mathbf{n}=\mathbf{1 0 0})\end{array}$ & $\begin{array}{c}\text { Controls } \\
(\mathbf{n = 5 0})\end{array}$ \\
\hline 1 & Smoking & $48(48 \%)$ & $15(30 \%)$ \\
\hline 2 & $\begin{array}{c}\text { Positive family } \\
\text { history }\end{array}$ & $33(33 \%)$ & $28(56 \%)$ \\
\hline 3 & Sedentary lifestyle & $23(23 \%)$ & $03(06 \%)$ \\
\hline 4 & Obesity & $20(20 \%)$ & $0(0 \%)$ \\
\hline \multicolumn{4}{|c|}{ Table 1. Comparison of Risk Factors } \\
\hline
\end{tabular}

Mean level of serum total calcium in subjects with systolic BP > $140 \mathrm{mmHg}$ was $9.10 \pm 1.04$ and in subjects with systolic $\mathrm{BP}<140 \mathrm{mmHg}$ was $8.99 \pm 1.18$. The difference is not statistically significant $(\mathrm{p}=0.09)$. Mean level of serum total calcium in subjects with diastolic BP $>90 \mathrm{mmHg}$ was $9.26 \pm$ 1.08 and in subjects with diastolic $\mathrm{BP}<90 \mathrm{~mm}$ Hg was $9.06 \pm$ 0.87 . The difference is not statistically significant $(p=0.12)$ (Table 2).

Mean level of ionic calcium in subjects with systolic BP > $140 \mathrm{mmHg}$ was $1.25 \pm 0.16$ and in subjects with systolic $\mathrm{BP}<$ $140 \mathrm{mmHg}$ was $1.21 \pm 0.19$. The difference is not statistically significant $(\mathrm{p}=0.47)$. Mean level of ionic calcium in subjects with diastolic BP > $90 \mathrm{mmHg}$ was $1.25 \pm 0.17$ and in subjects with diastolic $\mathrm{BP}<90 \mathrm{mmHg}$ was $1.21 \pm 0.12$. The difference is not statistically significant $(p=0.07)$ (Table 2$)$. 


\begin{tabular}{|c|c|c|c|c|c|}
\hline \multicolumn{2}{|c|}{$\begin{array}{c}\text { Blood } \\
\text { Pressure }\end{array}$} & $\begin{array}{c}\text { Mean Total } \\
\text { Calcium }\end{array}$ & P value & $\begin{array}{c}\text { Mean Ionic } \\
\text { Calcium }\end{array}$ & $\begin{array}{c}\text { P } \\
\text { value }\end{array}$ \\
\hline \multirow{2}{*}{ Systolic } & $>140$ & $9.10 \pm 1.04$ & \multirow{2}{*}{0.09} & $1.25 \pm 0.16$ & \multirow{2}{*}{0.47} \\
\cline { 2 - 3 } \cline { 5 - 6 } & $<140$ & $8.99 \pm 1.18$ & & $1.21 \pm 0.19$ & \\
\hline \multirow{2}{*}{ Diastolic } & $>90$ & $9.26 \pm 1.08$ & \multirow{2}{*}{0.12} & $1.25 \pm 0.17$ & \multirow{2}{*}{0.07} \\
\cline { 2 - 3 } & $<90$ & $9.06 \pm 0.87$ & & $1.21 \pm 0.12$ & \\
\hline \multicolumn{3}{|c|}{$\begin{array}{c}\text { Table 2. Correlation of Serum Total Calcium and Ionic } \\
\text { Calcium with Systolic and Diastolic Blood Pressure }\end{array}$} \\
\hline
\end{tabular}

'T' test is applied. *P value $<0.05$ is significant.

Maximum numbers of subjects (56\% of cases and $68 \%$ of controls) had serum total calcium levels in normal range, i.e. $8.8-10.4 \mathrm{mg} / \mathrm{dL}$. Mean total calcium levels are comparable in both the groups $(9.296 \pm 1.09$ in cases and $9.571 \pm 0.75$ in controls). Difference is not statistically significant $(p=0.113)$, (Table 3).

\begin{tabular}{|c|c|c|}
\hline $\begin{array}{c}\text { Serum Total } \\
\text { Calcium in } \mathbf{~ m g} / \mathbf{d L}\end{array}$ & $\begin{array}{c}\text { Cases } \\
(\mathbf{n = 1 0 0})\end{array}$ & $\begin{array}{c}\text { Controls } \\
(\mathbf{n = 5 0})\end{array}$ \\
\hline$<8.8$ & $28(28 \%)$ & $07(14 \%)$ \\
\hline $8.8-10.4$ & $56(56 \%)$ & $34(68 \%)$ \\
\hline$>10.4$ & $16(16 \%)$ & $09(18 \%)$ \\
\hline Mean Total calcium \pm SD & $9.296 \pm 1.09$ & $9.571 \pm 0.75$ \\
\hline \multicolumn{2}{|c|}{ Table 3. Comparison of Total Calcium Levels } \\
\hline
\end{tabular}

$P$ value $=0.113$. Unpaired t-test is applied, ${ }^{*} p$ significant if $<0.05, \mathrm{p}<0.01$ (Highly significant).

Maximum numbers of subjects $(64 \%$ of cases and $78 \%$ of controls) had ionic calcium levels in normal range, i.e. 1.1 $1.4 \mathrm{mmol} / \mathrm{L}$. Also mean ionic calcium levels were comparable in both the groups $(1.23 \pm 0.17$ in cases and $1.24 \pm 0.13$ in controls) and the difference is not statistically significant $(\mathrm{p}=$ 0.729) (Table 4).

\begin{tabular}{|c|c|c|}
\hline Ionic Calcium in mmol/L & $\begin{array}{c}\text { Cases } \\
(\mathbf{n = 1 0 0 )}\end{array}$ & $\begin{array}{c}\text { Controls } \\
(\mathbf{n = 5 0 )}\end{array}$ \\
\hline$<1.1$ & $20(20 \%)$ & $04(08 \%)$ \\
\hline $1.1-1.4$ & $64(64 \%)$ & $39(78 \%)$ \\
\hline$>1.4$ & $16(16 \%)$ & $07(14 \%)$ \\
\hline Mean I. Calcium \pm SD & $1.23 \pm 0.17$ & $1.24 \pm 0.13$ \\
\hline \multicolumn{2}{|c|}{ Table 4. Comparison of Ionic Calcium Levels } \\
\hline
\end{tabular}

$P$ value $=0.729$. Unpaired $t$-test is applied, ${ }^{*} p$ significant if $<0.05, \mathrm{p}<0.01$ (Highly significant).

Mean level of serum total calcium in young hypertensives i.e. age $<59$ years was $9.05 \pm 1.18$ and in elderly hypertensives i.e. age $>59$ years was $9.65 \pm 0.86$. The difference is statistically significant $\left(\mathrm{p}=0.03^{*}\right)$. Mean level of ionic calcium in young hypertensives, i.e. age $<59$ years was $1.22 \pm 0.20$ and in elderly hypertensives i.e. age $>59$ years was $1.25 \pm 0.15$. The difference is statistically significant $(\mathrm{p}=$ $0.047^{*}$ ) (Table 5).
Mean level of serum total calcium in male hypertensives was $9.06 \pm 1.04$ and in female hypertensives was $9.59 \pm 1.10$. The difference is statistically significant $\left(p=0.02^{*}\right)$. Mean level of ionic calcium in male hypertensives was $1.23 \pm 0.17$ and in female hypertensives was $1.25 \pm 0.17$. The difference is statistically significant $\left(\mathrm{p}=0.041^{*}\right)$ (Table 5).

\begin{tabular}{|c|c|c|c|c|c|}
\hline & & $\begin{array}{c}\text { Mean Total } \\
\text { Calcium }\end{array}$ & $\begin{array}{c}\mathbf{P} \\
\text { value }\end{array}$ & $\begin{array}{c}\text { Mean Ionic } \\
\text { Calcium }\end{array}$ & $\begin{array}{c}\text { P } \\
\text { value }\end{array}$ \\
\hline \multirow{2}{*}{ Age } & $<59$ & $9.05 \pm 1.18$ & \multirow{2}{*}{$0.03 *$} & $1.22 \pm 0.20$ & \multirow{2}{*}{$0.047^{*}$} \\
\cline { 2 - 5 } & $>59$ & $9.65 \pm 0.86$ & & $1.25 \pm 0.15$ & \\
\hline \multirow{2}{*}{ Gender } & Male & $9.06 \pm 1.04$ & \multirow{2}{*}{$0.02 *$} & $1.23 \pm 0.17$ & \multirow{2}{*}{$0.041^{*}$} \\
\cline { 2 - 4 } & Female & $9.59 \pm 1.10$ & & $1.25 \pm 0.17$ & \\
\hline
\end{tabular}

Table 5. Comparison of Serum Total Calcium and Ionic

Calcium Levels according to Age and Gender in Cases

$20 \%$ of the cases were obese i.e. BMI $\geq 30$, also another $34 \%$ of cases were in overweight range i.e. 25 - 29.9. BMI was significantly higher in cases as compared to controls (mean BMI $25.67 \pm 4.35$ in cases and $22.51 \pm 1.91$ in controls) and the difference is highly significant $(p=0.0001)$.

Triglyceride levels were significantly higher in cases as compared to controls (Mean TG $145.08 \pm 20.40$ in cases and $135.10 \pm 21.33$ in controls) and the difference is highly significant $(p=0.007)$. Total cholesterol and HDL levels were comparable in both the groups as the difference is not statistically significant $(\mathrm{p}=0.081$ for total cholesterol and $\mathrm{p}=$ 0.313 for HDL levels).

Mean serum total calcium level in cases with BMI $<30$ was $9.02 \pm 0.94$ and that in cases with BMI $>30$ was $10.41 \pm$ 0.99 . The difference is statistically significant $(\mathrm{p}=0.01)$. Mean ionic calcium level in cases with $\mathrm{BMI}<30$ was $1.23 \pm 0.17$ and that in cases with BMI $>30$ was $1.29 \pm 0.17$. The difference is not statistically significant $(\mathrm{p}=0.117)$ (Table 6).

Mean serum total calcium level in cases with serum total cholesterol $<200$ was $9.01 \pm 0.93$ and that in cases with serum total cholesterol $>200$ was $10.40 \pm 0.98$. The difference is statistically significant $(p=0.01)$. While difference in mean ionic calcium level in this group is not statistically significant $(p=0.117)$ (Table 6).

Mean serum total calcium level in cases with serum triglycerides $<160$ was $9.03 \pm 0.93$ and that in cases with serum triglycerides $>160$ was $10.28 \pm 1.10$. The difference is statistically significant $(p=0.01)$. While difference in mean ionic calcium level in this group is not statistically significant $(\mathrm{p}=0.059)$ (Table 6).

Mean serum total calcium level in cases with HDL $<40$ was $10.20 \pm 1.24$ and that in cases with HDL $>40$ was $9.21 \pm$ 1.23. The difference is statistically significant $(p=0.013)$. While difference in mean ionic calcium level in this group is not statistically significant $(p=0.190)$ (Table 6). 


\begin{tabular}{|c|c|c|c|c|c|c|}
\hline Risk Factors & & Cases $(n=100)$ & Mean Total Calcium & P value & Mean Ionic Calcium & P value \\
\hline \multirow{2}{*}{ BMI } & $<30$ & 80 & $9.02 \pm 0.94$ & \multirow{2}{*}{$0.01^{*}$} & $1.23 \pm 0.17$ & \multirow{2}{*}{0.117} \\
\hline & $>30$ & 20 & $10.41 \pm 0.99$ & & $1.29 \pm 0.17$ & \\
\hline \multirow{2}{*}{$\begin{array}{l}\text { Serum Total } \\
\text { Cholesterol }\end{array}$} & $<200$ & 80 & $9.01 \pm 0.93$ & \multirow{2}{*}{$0.01^{*}$} & $1.22 \pm 0.16$ & \multirow{2}{*}{0.117} \\
\hline & $>200$ & 20 & $10.40 \pm 0.98$ & & $1.29 \pm 0.17$ & \\
\hline \multirow{2}{*}{ Triglycerides } & $<160$ & 79 & $9.03 \pm 0.93$ & \multirow{2}{*}{$0.01^{*}$} & $1.22 \pm 0.16$ & \multirow{2}{*}{0.059} \\
\hline & $>160$ & 21 & $10.28 \pm 1.10$ & & $1.30 \pm 0.17$ & \\
\hline \multirow{2}{*}{ HDL } & $<40$ & 8 & $10.20 \pm 1.24$ & \multirow{2}{*}{$0.013^{*}$} & $1.31 \pm 0.21$ & \multirow{2}{*}{0.190} \\
\hline & $>40$ & 92 & $9.21 \pm 1.23$ & & $1.23 \pm 0.16$ & \\
\hline
\end{tabular}

Table 6. Comparison of Serum Total Calcium and Ionic Calcium in Cases according to BMI and Lipid Profile

' $\mathrm{t}$ ' test is applied. ${ }^{*} \mathrm{P}$ value $<0.05$ is significant.

In order to study the association of total calcium and ionic calcium with all cardiovascular risk factors (in controls) linear regression analysis was performed.

Results showed that no one of the cardiovascular risk factors was associated with total calcium and ionic calcium levels, as the correlation was not significant $(\mathrm{p}>0.05)$ (Table 7).

\begin{tabular}{|c|c|c|c|}
\hline \multirow{2}{*}{$\begin{array}{l}\text { Independent } \\
\text { Variable } \\
\text { (Controls) }\end{array}$} & \multirow[b]{2}{*}{ Parameters } & \multicolumn{2}{|c|}{ Dependent Variables } \\
\hline & & $\begin{array}{c}\text { Total } \\
\text { Calcium }\end{array}$ & $\begin{array}{c}\text { Ionic } \\
\text { Calcium }\end{array}$ \\
\hline \multirow{2}{*}{ SBP } & $\begin{array}{l}\text { Correlation } \\
\text { Coefficient }\end{array}$ & -0.188 & -0.147 \\
\hline & P-value & 0.192 & 0.309 \\
\hline \multirow[t]{2}{*}{ DBP } & $\begin{array}{l}\text { Correlation } \\
\text { Coefficient }\end{array}$ & -0.220 & -0.145 \\
\hline & P-value & 0.125 & 0.315 \\
\hline \multirow[t]{2}{*}{ BMI } & $\begin{array}{c}\text { Correlation } \\
\text { Coefficient }\end{array}$ & 0.070 & 0.025 \\
\hline & P-value & 0.631 & 0.865 \\
\hline \multirow{2}{*}{$\begin{array}{c}\text { Total } \\
\text { Cholesterol }\end{array}$} & $\begin{array}{l}\text { Correlation } \\
\text { Coefficient }\end{array}$ & -0.088 & -0.030 \\
\hline & P-value & 0.544 & 0.837 \\
\hline \multirow[t]{2}{*}{ HDL } & $\begin{array}{l}\text { Correlation } \\
\text { Coefficient }\end{array}$ & -0.071 & -0.031 \\
\hline & P-value & 0.624 & 0.832 \\
\hline \multirow[t]{2}{*}{$\mathrm{TG}$} & $\begin{array}{l}\text { Correlation } \\
\text { Coefficient }\end{array}$ & 0.418 & 0.316 \\
\hline & P-value & $0.003^{*}$ & $0.025^{*}$ \\
\hline \multicolumn{4}{|c|}{$\begin{array}{l}\text { Table 7. Linear Regression Analysis showing } \\
\text { association of TOTAL CALCIUM and Ionic Calcium } \\
\text { with all Cardiovascular Risk Factors in Controls }\end{array}$} \\
\hline
\end{tabular}

*Significant if $\mathrm{p}<0.05, \mathrm{p}<0.01$ (Highly significant).

In order to study the association of total calcium and ionic calcium with all cardiovascular risk factors (in cases) linear regression analysis was performed.

Results showed that some of the cardiovascular risk factors like BMI, high total cholesterol and triglyceride levels were significantly associated with high total calcium level and the correlation was highly significant $(\mathrm{p}<0.01)$. While risk factors like SBP, DBP and HDL levels did not correlate, significantly with total calcium levels (Table 8).

Also, the results showed that only high total cholesterol levels and high triglyceride levels were significantly associated with high ionic calcium level and the correlation was statistically significant $(\mathrm{p}<0.05)$, while other risk factors like SBP, DBP, BMI and HDL levels were not associated with ionic calcium levels as the correlation was not statistically significant $(\mathrm{p}>0.05)$ (Table 8).

\begin{tabular}{|c|c|c|c|}
\hline \multirow{2}{*}{$\begin{array}{l}\text { Independent } \\
\text { Variable } \\
\text { (Cases) }\end{array}$} & \multirow[b]{2}{*}{ Parameters } & \multicolumn{2}{|c|}{ Dependent Variables } \\
\hline & & $\begin{array}{c}\text { Total } \\
\text { Calcium }\end{array}$ & $\begin{array}{c}\text { Ionic } \\
\text { Calcium }\end{array}$ \\
\hline \multirow[t]{2}{*}{ SBP } & $\begin{array}{l}\text { Correlation } \\
\text { Coefficient }\end{array}$ & 0.087 & 0.100 \\
\hline & P-value & 0.390 & 0.322 \\
\hline \multirow[t]{2}{*}{ DBP } & $\begin{array}{l}\text { Correlation } \\
\text { Coefficient }\end{array}$ & -0.095 & 0.091 \\
\hline & P-value & 0.345 & 0.369 \\
\hline \multirow[t]{2}{*}{ BMI } & $\begin{array}{l}\text { Correlation } \\
\text { Coefficient }\end{array}$ & 0.524 & 0.113 \\
\hline & P-value & $0.0001^{*}$ & 0.263 \\
\hline \multirow{2}{*}{$\begin{array}{c}\text { Total } \\
\text { Cholesterol }\end{array}$} & $\begin{array}{c}\text { Correlation } \\
\text { Coefficient }\end{array}$ & 0.483 & 0.229 \\
\hline & P-value & $0.0001^{*}$ & $0.022^{*}$ \\
\hline \multirow[t]{2}{*}{ HDL } & $\begin{array}{l}\text { Correlation } \\
\text { Coefficient }\end{array}$ & -0.181 & -0.080 \\
\hline & P-value & 0.071 & 0.426 \\
\hline \multirow[t]{2}{*}{ TG } & $\begin{array}{l}\text { Correlation } \\
\text { Coefficient }\end{array}$ & 0.334 & 0.249 \\
\hline & P-value & $0.001^{*}$ & $0.013^{*}$ \\
\hline \multicolumn{4}{|c|}{$\begin{array}{l}\text { Table 8. Linear Regression Analysis showing } \\
\text { association of Total Calcium and Ionic Calcium } \\
\text { with all Cardiovascular Risk Factors in Cases }\end{array}$} \\
\hline
\end{tabular}

*Significant if $\mathrm{p}<0.05, \mathrm{p}<0.01$ (Highly significant).

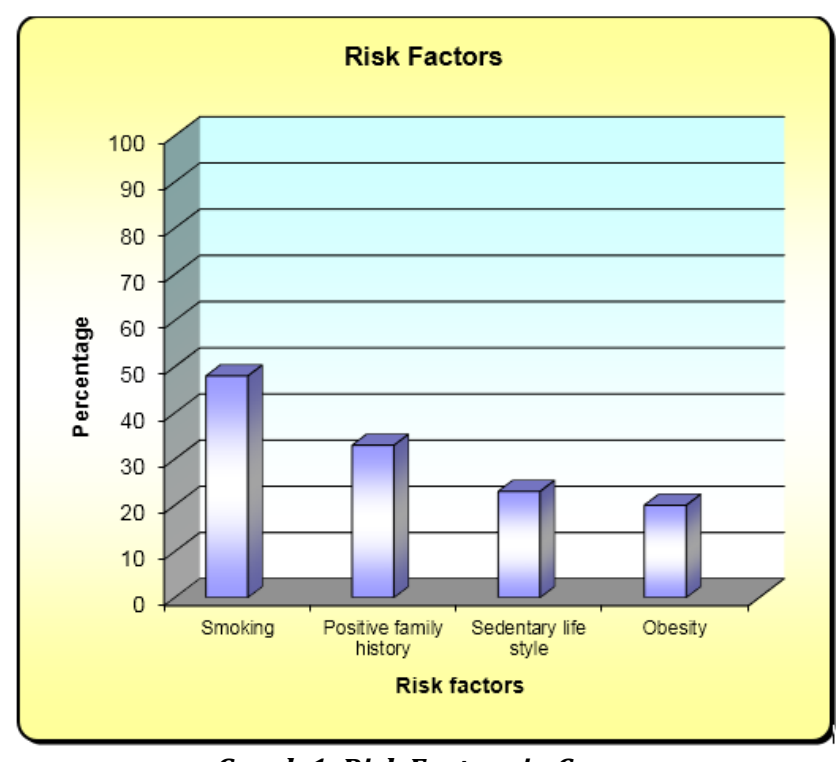

Graph 1. Risk Factors in Cases 


\section{DISCUSSION}

Essential hypertension is multifactorial. Many hypotheses were proposed about possible mechanisms for underlying essential hypertension like deranged serum electrolytes and water balance. One of the physiologically important ions in the serum is calcium. Present study was undertaken to look for levels of total and ionic serum calcium levels in patients with essential hypertension and those without hypertension.

In present study, there was no significant difference between mean level of serum total calcium in subjects with systolic BP > $140 \mathrm{mmHg}$ was $9.10 \pm 1.04$ and in subjects with systolic $B P<140 \mathrm{mmHg}$ was $8.99 \pm 1.18(\mathrm{p}=0.09)$. Also, there was no significant difference between mean level of serum total calcium in subjects with diastolic BP $>90 \mathrm{mmHg}$ was $9.26 \pm 1.08$ and in subjects with diastolic BP $<90 \mathrm{mmHg}$ was $9.06 \pm 0.87(\mathrm{p}=0.12)$.

Mean level of ionic calcium in subjects with systolic BP > $140 \mathrm{mmHg}$ was $1.25 \pm 0.16$ and in subjects with systolic BP < $140 \mathrm{mmHg}$ was $1.21 \pm 0.19$. The difference is not statistically significant $(p=0.47)$. Mean level of ionic calcium in subjects with diastolic $\mathrm{BP}>90 \mathrm{mmHg}$ was $1.25 \pm 0.17$ and in subjects with diastolic $\mathrm{BP}<90 \mathrm{mmHg}$ was $1.21 \pm 0.12$. The difference is not statistically significant $(\mathrm{p}=0.07)$.

$\mathrm{K}$ Sudhakar et $\mathrm{al}^{4}$ in an Indian study found that the mean serum calcium levels in males and females were $2.53 \pm 0.26$ and $2.51 \pm 0.21(\mathrm{mmol} / \mathrm{L})$ respectively in control group and the same were significantly $(\mathrm{p}<0.01)$ decreased in males $(2.27 \pm 0.36)$ and females $(2.20 \pm 0.35)$ in hypertensive group. The mean serum calcium level in control was $2.52 \pm$ 0.24 as against $2.23 \pm 0.36$ in hypertensives. In the firstdegree relatives also, the calcium level was significantly decreased $(2.42 \pm 0.24, p<0.01)$ when compared with the controls. The result showed that serum calcium was significantly $(\mathrm{p}<0.01)$ decreased in both males and females of essential hypertension and their first-degree relatives when compared to the normotensive controls. This is the first study in Indian population.

Previously, Rolf Jorde et $\mathrm{al}^{1}$ in Tromso study found that serum calcium was significantly $(\mathrm{P}=0.001)$ and positively associated with systolic and diastolic blood pressure. The relation was found to be present within each age group and was similar in men and women. Phillips AN et al,11 Kesteloot $\mathrm{H}$ et $\mathrm{al}^{12}$ and Lind $\mathrm{L}$ et $\mathrm{al}^{2}$ also found the same results. Also Weidmann et $\mathrm{al}^{13}$ found a significant correlation between changes in systolic and diastolic BP and increment in serum calcium levels.

Manfred S Green and Eliezer Jucha ${ }^{14}$ found that serum calcium was found to be significantly correlated with systolic BP $(r=0.18, p<0.001)$ only among those under the age of 40 . This association persisted after adjustment for age and serum albumin levels, but was not statistically significant after further adjustment for serum cholesterol. These findings contribute to the evidence implicating calcium as a key factor in the control of blood pressure. However, the fact that adjustment for serum cholesterol levels eliminated the significance of the association between BP and serum calcium suggests that this association may not be direct. Bulpitt CJ et $\mathrm{al}^{15}$ too found direct relation of serum calcium and BP. They found such a correlation with systolic BP only.

In conjunction with present study, McCarron DA ${ }^{16}$ found no difference in serum calcium between hypertensive and normotensive group.
In present study, smoking was the most common risk factor observed and was seen in $48 \%$ of the cases. $33 \%$ of the cases had hypertension in first-degree relatives. Sedentary lifestyle was observed in $23 \%$ of the cases. In control group $30 \%$ subjects were smokers and $56 \%$ subjects had positive family history of hypertension. Sedentary lifestyle was present in 6\% controls. Franklin et al found 67\% patients of essential hypertension had a hypertensive first-degree relative. ${ }^{17}$

\section{Ionic Calcium Levels}

In our study, maximum numbers of subjects (64\% of cases and $78 \%$ of controls) had ionic calcium levels in normal range, i.e. 1.1 - $1.4 \mathrm{mmol} / \mathrm{L}$. Also mean ionic calcium levels were comparable in both the groups $(1.23 \pm 0.17$ in cases and $1.24 \pm 0.13$ in controls) and the difference was not statistically significant $(p=0.729)$. It suggests that ionic calcium levels are within normal range in patients with essential hypertension in the study population.

Previously, LM Resnick et $\mathrm{al}^{9}$ showed that serum level of ionised calcium were lower in patients with low renin hypertension and higher in patients with high renin hypertension than in those with normal renin hypertension $(\mathrm{p}<0.001$ and $\mathrm{p}<0.05$, respectively). Altogether, the range of plasma renin activity in essential hypertension shows a continuous positive correlation with the serum ionised calcium level $(\mathrm{r}=0.44$ and $\mathrm{p}<0.001)$.

Study by Strazzulo and coworkers ${ }^{18}$ also found no difference in ionised calcium concentration between patients with hypertension and a matched normotensive group. However, our study did not find any significant change in ionic calcium levels in essential hypertension.

\section{Limitations}

Sample size was less. Also, serum total calcium levels were not corrected for serum albumin levels.

\section{CONCLUSION}

1. Serum total calcium as well as ionic calcium levels does not have any significant correlation with the essential hypertension in the study population.

2. Elderly hypertensives have significantly higher levels of serum total calcium as well as ionic calcium compared to young hypertensives.

3. Young hypertensives have significantly lower levels of serum total calcium as compared to normotensives.

4. Female hypertensives have significantly higher levels of serum total calcium as well as ionic calcium compared to male hypertensives.

5. Male hypertensives have significantly lower levels of serum total calcium as compared to normotensives.

6. Serum total calcium has significant linear correlation with cardiovascular risk factors like high BMI, high levels of total cholesterol, Triglycerides and low HDL; however, ionic calcium does not have any significant correlation with BMI and lipid profile.

\section{Implications}

Serum calcium total as well as ionic is not associated with hypertension, but regardless of this strong linear correlation of serum total calcium with BMI and hyperlipidaemia may suggest it to be a component of metabolic syndrome. 


\section{REFERENCES}

[1] Jorde R, Sundsfjord J, Fitzgerald P, et al. Serum calcium and cardiovascular risk factors and diseases: the Tromso study. Hypertension 1999;34(3):484-90.

[2] Lind L, Jakobsson S, Lithell H, et al. Relation of serum calcium concentration to metabolic risk factors for cardiovascular diseases. $\mathrm{Br}$ Med J 1988;297(6654):960-3.

[3] Lind L, Skarfors E, Berglund L, et al. Serum calcium: a new, independent, prospective risk factor for myocardial infarction in middle-aged men followed for 18 years. J Clin Epidemiol 1997;50(8):967-73.

[4] Sudhakar K, Sujatha M, RameshBabu S, et al. Serum calcium levels in patients with essential hypertension \& their first degree relatives. Ind J Clin Biochem 2004;19(1):21-3.

[5] Belizan Jm, Villar J, Pineda 0, et al. Reduction of blood pressure with calcium supplementation in young adults. J Am Med Assoc 1983;249(9):1161-5.

[6] McCarron DA. Calcium, symposium notes: nonpharmacological management of hypertension. (National Kidney Foundation). 1994: 34-8.

[7] Osborne CG, McTyre RB, Dudek J, et al. Evidence for the relationship of calcium to blood pressure. Nutr Rev 1996;54(12):365-81.

[8] Sempos C, Cooper R, Kovar MG, et al. Dietary calcium and blood pressure in National Health and Nutrition Examination Surveys I and II. Hypertension 1986;8(11):1067-74.
[9] Resnick LM, Laragh JH, Sealey JE, et al. Divalent cations in essential hypertension. Relation between serum ionized calcium, magnesium and plasma renin activity. N Eng J Med 1983;309(15):888-91.

[10] 7th report of Joint National Committee, a WHO expert committee on prevention, detection, evaluation and treatment of high blood pressure. 2003:19.

[11] Phillips AN, Shaper AG. Serum calcium and blood pressure. J Hum Hypertens 1991;5(6):479-84.

[12] Kesteloot H, Geboers J. Calcium and blood pressure. The Lancet 1982;319(8276):813-5.

[13] Weidman P. Systolic and diastolic BP and increment in serum calcium \& ionic calcium and relation to plasma renin activity. Annual Int Med 1972;76:741.

[14] Green MS, Jucha E. Interrelationships between blood pressure, serum calcium and other biochemical variables. Int Journal Epidemiol 1987;16(4):532-6.

[15] Bulpitt CJ, Hodes C, Everitt MG. Epidemiology of cardiovascular risk factors in Catalonia. Eur J Epidemiol 1976;30:158-62.

[16] McCarron DA. Low serum concentrations of ionized calcium in patients with hypertension. N Eng J Med 1982:307;226-8

[17] Franklin SN. Epidemiological and pathophysiological correlation of obesity and essential hypertension. J Am Med Assoc 1972;220:1209.

[18] Strazzullo P, Nunziata V, Cirilio M, et al. Abnormalities of calcium metabolism in essential hypertension. Clinical Science (London) 1983;65(2):137-41. 